\title{
KESEHATAN SEBAGAI SYARAT PERNIKAHAN: Studi Pandangan Ulama Kabupaten Gayo Lues - Aceh
}

\author{
Jemian \\ Mahasiswa Pascasrajan UIN Maliki Malang \\ Prodi. Al-Ahwal al-Syakhsyiyyah 2011. HP. 081375877687 \\ email: Lemian80@yahoo.com
}

\begin{abstract}
The purpose of marriage is to achieve family sakinah, mawaddah, wa-rahmah. The achievement of this purpose will be known from some indications, such as the achievement of peace, having child, as well as satisfy the biological needs (sexual). Many couples of marriage in Gayo Lues regency taken a divorcing decision or to be polygamist for husband because they could not fulfil the biological needs, because of the unhealthy spouse both physically and spiritually. The research aimed to find out the scholars' perception about divorcing or being polygamist and to find out the scholars' perception about health issue was made as a requirement of marriage. The method of this research collecting data are observation, interview, and documentation, then are explained on descriptive interpretative through qualitative approach. This research resulted that the scholars of Gayo Lues regency allowed the divorcing decision with necessary reasons such as health and most major of them allowed the health issue which was made as the requirement of marriage. As a conclusion of this research, divorce was not a forbidden act to be applied as long as it based on a necessary reason and it was more beneficial than defending the marriage, in spite of the fact that it was hated by God; and the healthy term could be made as a requirement of the marriage as the perfection of requirement not a validity one on purpose to minimize the divorcing decision as the effect of illness of spouse both physically and psychologically.
\end{abstract}

Tujuan pernikahan dalam Islam adalah mencapai keluarga sakinah, mawaddah wa rahmah. Tujuan ini kan tercapai apabila beberapa kebutuhan berikut dapat terpenuhi; ketentraman jiwa, kelestarian keturunan, serta kebutuhan seksual. Di 
Kabupaten Gayo Lues ada suami atau istri yang mengambil keputusan untuk bercerai, atau berpoligami bagi laki-laki, dengan alasan tidak terpenuhinya beberapa kebutuhan tersebut. Suami atau istri tidak dapat memenuhi beberapa kebutuhan di atas karena tidak sehat (tidak memiliki alat reproduksi yang sehat), akibatnya tidak mampu untuk bersetubuh atau berketurunan. Penelitian ini bertujuan untuk memaparkan pandangan ulama terhadap perceraian atau poligami tersebut, dan pandangan mereka bila kesehatan tersebut dijadikan sebagai syarat penikahan. Data dikumpulkan melalui observasi, wawancara, dan dokumentasi, kemudian disampaikan dalam bentuk deksriptif interpretatif karena merupakan penelitian kualitatif. Dari penelitiaan ini ditemukan bahwa ulama Gayo Lues membolekan perceraian atau poligami jika terdapat alasanalasan yang kuat untuk melakukannya, salah satunya adalah alasan kesehatan, dan mayoritas setuju kesehatan dijadikan syarat nikah. Sebagai kesimpulan, perceraian atau poligami bukanlah perbuatan yang haram sehingga boleh dilakukan untuk memenuhi kebutuhan seksual dari pada berzina atau untuk mencari keturunan, jika dipandang hal tersebut lebih bermanfaat daripada mempertahankan keluarga yang ada walaupun cerai sangat dibenci oleh Allah. Dan kesehatan boleh dijadikan sebagai syarat pernikahan, untuk meminimalisir perceraian, perselingkuhan, dan perzinaan.

Key words: health, requirement, marriage, and Islamic scholars' perception

\section{Pendahuluan}

Islam memerintahkan untuk menikah bagi seseorang yang mempunyai kemampuan (istia'ah) untuk ba'ah. Artinya barang siapa yang sudah mampu untuk menikah baik lahir maupun batin (sehat lahir batin), maka dianjurkan untuk segera menikah. Secara spesifik, Rasulullah SAW menyebutkan:

"Wahai para pemuda, barang siapa yang telah mampu maka hendaklah ia menikah, karena hal itu lebih menjaga pandangan dan kemaluan. Barang siapa yang belum mampu, hendaklah ia berpuasa, karena puasa bisa menjadi perisai baginya" (HR Muslim).

Kata al Ba'ah secara etimologi artinya adalah jima', bersetubuh, hubungan intim, atau biaya/ material. Maksudnya, siapa yang sudah sanggup jima' maka hendaklah ia menikah, atau siapa yang ada biaya hendaklah ia menikah. Akan tetapi yang lebih bagusnya adalah menggabungkan makna keduanya, yaitu siapa yang sudah mampu lahir-batin maka hendaklah ia menikah (HR Abi Dawud).

Banyak ditemui di Kabupaten Gayo Lues suami atau istri mengambil keputusan untuk bercerai, atau berpoligami bagi suaminya bahkan lebih parah lagi adalah berselingkuh karena tidak terpenuhi kebutuhan seksualnya, atau 
karena tidak mendapat keturunan.

Bukti autentik bahwa perceraian merupakan jalan yang ditempuh karena kebutuhan biologis tidak terpenuhi dan tidak ada keturunan, adalah peristiwa seorang istri yang menggugat suaminya di Mahkamah Syar'iyah (Pengadilan Agama) Kabupaten Gayo Lues, karena suaminya tidak dapat memberikan keturunan akibat mengidap penyakit lemah syahwat, dan gugatannya tersebut sudah diputus oleh Mahkamah Syar'iyah Kabupaten Gayo Lues No. 61/ Pdt.G/2011/MS-BKJ.

Dalam perkaranya disebutkan bahwa istri menggugat cerai suaminya karena tidak ada keturunan yang disebabkan suami mengidap penyakit lemah syahwat, dan kedua belah pihak sudah berusaha untuk sembuh dengan berobat baik secara medis maupun non medis, akan tetapi tetap tidak membuahkan hasil. Sehingga dalam putusannya Mahkamah Syari'yah mengabulkan gugatan penggugat dengan menyatakan jatuh talak satu ba'in syugra.

Merujuk kepada pengertian nikah yang (secara bahasa) bermakna berkumpul dan bergabung (Bukhari, 1400H: 354). Nikah dalam bahasa Arab juga bermakna mengumpulkan, saling memasukkan, dan biasanya digunakan untuk definisi wa'i (jima'). Terminology fiqih, nikah berarti akad yang mengandung pembolehan hubungan intim (al wa'u). Sedangkan secara syari'at berarti sebuah akad yang mengandung pembolehan bersenang-senang dengan perempuan, berhubungan intim, menyentuh, mencium, memeluk, dan sebagainya, jika perempuan tersebut bukan termasuk mahram dari segi nasab, sesusuan, dan keluarga (Wahbah az Zuaili, 2001: 39). Makna pernikahan tersebut sejalan dengan makna $b a^{\prime} a h$ yang terkandung di dalam hadits di atas yang memerintah untuk menikah bagi orang yang sudah mampu.

Sejalan dengan pengertian pernikahan di atas, secara umum dapat digambarkan bahwa tujuan pernikahan adalah membentuk keluarga sakinah, mawaddah, wa rahmah. Hal ini sesuai dengan firman Allah SWT di dalam al Quran, yaitu:

"Dan di antara tanda-tanda (kekuasaan-Nya) ialah Dia menciptakan untukmu istri-istri dari jenismu sendiri, supaya kamu merasa nyaman kepadanya, dan dijadikanNya di antaramu mawadah dan rahmah. Sesungguhnya pada yang demikian itu benar-benar terdapat tanda-tanda bagi kaum yang berpikir"(QS ar Rum: 21).

Tujuan pernikahan dapat tercapai apabila terpenuhi beberapa kebutuhan berikut, diantaranya ketentraman jiwa, kelestarian keturunan, serta kebutuhan seksual (Burhanuddin S, 2010: 47). Masalah pemenuhan kebutuhan seksual, merupakan kewajiban dan hak masing-masing suami istri dalam ikatan perkawinan. Hal ini banyak dijelaskan oleh Rasulullah SAW diantaranya 
adalah hak dan kewajiban untuk saling bergaul/ jima:

"Dari Sulaiman bin Amr bin al Ahwash berkata, ayahku pernah bercerita kepadaku bahwasanya ia pernah menyaksikan haji wada' bersama Rasulullah SAW. Beliau bersabda, ingatlah sesungguhnya istri-istri kalian mempunyai hak atas kalian dan kalianpun mempunyai hak atas istri-istri kalian" (HR Tirmizi).

Hadits di atas menunjukkan adanya keseimbangan antara hak dan kewajiban suami istri, salah satunya adalah hak dan kewajiban dalam pemenuhan kebutuhan seksual. Berikut ini digambarkan bagaimana kewajiban dan hak suami istri tersebut.

Ketentuan yang berhubungan dengan hak suami terhadap isteri dalam jimak, istri tidak boleh menolak ajakan suami untuk bersetubuh, artinya dengan adanya hak suami terhadap istri untuk mendapatkan kenikmatan bersetubuh, berarti istri berkewajiban melayaninya sebagaimana sabda Rasulullah SAW:

"Apabila suami mengajak isterinya (bersenggama) lalu isterinya menolak melayaninya dan suami sepanjang malam jengkel maka (isteri) dilaknat malaikat sampai pagi" (HR Muslim).

“... dari Abu Hurairah, bahwa Rasulullah SAW bersabda: Seorang istri tidak halal berpuasa ketika suami ada di rumah tanpa izinnya" (HR Bukhari).

Lalu, di sisi lain istri juga mempunyai hak untuk bersetubuh atas suaminya, sehingga di sini suami mempunyai kewajiban untuk melayaninya. Sebagaimana sabda Rasulullah SAW:

"Wahai Abdullah, bukankah telah dikabarkan kepadaku bahwa engkau biasa puasa di (setiap) siang hari dan shalat di (sepanjang) malam hari? Ia, wahai Rasulullah, jawabku. Beliau lalu memberikan nasihat: jangan engkau lakukan lagi. Puasalah dan berbukalah. Bangunlah untuk shalat dan tidurlah. Karena tubuhmu memiliki hak terhadapmu. Matamu pun punya hak terhadapmu. Demikian pula istrimu memiliki hak terhadapmu (HR. Bukhari).

Sebuah riwayat menyebutkan bahwa dalam berhubungan badan/ jima', suami harus menunggu sampai keduanya merasa puas. Jika seorang di antara kamu bersetubuh dengan istrinya, maka hendaklah ia melakukannya dengan sungguh-sungguh. Kemudian kalau ia sudah terlebih dahulu merasakan orgasme sebelum istri merasakannya, hendaknya ia tidak terburu-buru mencabut (penisnya) sampai istri terpenuhi hajatnya/ memperoleh orgasme (Thalib, 1995: 52).

Hal di atas menunjukkan bahwa masalah kesehatan dalam pernikahan perlu mendapat perhatian, sebab apabila seseorang memilih cerai atau poligami maupun selingkuh karena tidak mendapat kebutuhan seksual atau 
tidak mendapat keturunan dari pasangannya, akan banyak menimbulkan efek yang lain, seperti putusnya persaudaraan antara pihak suami dan istri yang bercerai bahkan menimbulkan kebencian antara keduanya, rusaknya tatanan kehidupan sosial seperti maraknya perzinaan, bahkan bisa sampai kepada pembunuhan apabila tetap mempertahankan keluarga yang tidak dapat memenuhi kebutuhan seksualnya.

Dari permasalahan di atas, penulis ingin melihat bagaimana pandangan ulama terhadap perceraian atau poligami karena pasangan tidak sehat, yang berakibat tidak terpenuhi kebutuhan seksual atau tidak mendapat keturunan. Dan bagaimana pandangan ulama apabila kesehatan dijadikan sebagai syarat pernikahan.

\section{Metode Penelitian}

Penelitian ini merupakan penelitian lapangan (Nasution, 2008: 124). Jenis penelitian adalah kualitatif deskriftif karena dalam pelaksanaannya meliputi data, analisis dan interpretasi dari data yang diperoleh, serta memaparkan realitas yang ada (Asikin dkk, 2006: 25). Dengan kata lain, penelitian ini menuturkan dan menafsirkan data yang ada. Sehingga peneliti menyatu dengan situasi dan fenomena yang diteliti. Peneliti merupakan perencana, pelaksana pengumpul data, dan sebagai pelopor penelitian ini (Moloeng, 2002: 162). Bahkan dalam penelitian ini posisi peneliti menjadi instrument kunci (the key instrument) (Sugiono, 2008: 233). Karena untuk dapat memahami makna dan penafsiran terhadap fenomena-fenomena yang terjadi di lapangan maka dibutuhkan keterlibatan langsung peneliti terhadap objek penelitian. Sumber pengumpulan data diperoleh dari orang (person), tempat (palce), dan paper melalui observasi langsung, wawancara dan dokumentasi (Ahmad, 2005: 71).

Penelitian ini bertumpu pada analisis data, yakni kegiatan mengolah data yang dikumpulkan dari lapangan, pustaka, dan dokumentasi sehingga menjadi seperangkat data. Langkah-langkah dalam penelitian ini bisa dirangkum sebagai berikut: (1) heuristik, yaitu mencari dan mengumpulkan segala sumber-sumber, (2) kritik, yaitu memberi penilaian terhadap data serta menganalisa data dan sumber data, (3) interpretasi, yaitu menafsirkan keterangan dari berbagai sumber dan mensintesiskan hasil penfasiran tersebut dalam rangka pemikiran yang logis dan sistematis, dan (4) pelaporan, yaitu penulisan laporan penelitian yang dibuat dengan mengkonstruksi pemikiran berdasarkan fakta-fakta dan sumber data ke dalam bentuk tulisan yang objektif 
dan dapat dipertanggungjawabkan secara ilmiah (Hamzah, 2011: 113-132).

\section{Kesehatan dalam pernikahan}

Istilah sehat atau kesehatan berasal dari bahasa Arab yaitu sihah, yang berarti hilangnya penyakit, atau tidak adanya penyakit pada tubuh, atau terlepas dari segala cacat (Muhammad, 2007: 127).

Masalah kesehatan sangat berpengaruh dalam menentukan sebuah keluarga, baik dari segi keberlangsungan keutuhan keluarga maupun kelanjutan keturunan. Maka ada beberapa hal tentang kesehatan yang perlu diperhatikan, yaitu:

\section{Subur}

Berkaitan dengan syarat kesehatan dalam pernikahan, Rasulullah memerintahkan untuk menikah dengan orang-orang yang subur, artinya dari segi kesehatan tidak ada masalah untuk melahirkan dan berketurunan. Karena salah satu tujuan dari pernikahan adalah untuk melestarikan manusia di muka bumi ini sebagai khalifah Allah SWT.

Hal yang ditakutkan bagi laki-laki atau perempuan adalah mandul atau kemandulan, dalam bahasa kedokteran disebut infertilitas. Infertilitas merupakan istilah yang dipakai untuk menyebut pasangan yang gagal untuk hamil dan mempunyai anak setelah berusaha selama setahun melaksanakan hubungan seksual secara teratur dan tidak menggunakan alat kontrasepsi. Perempuan yang berhasil hamil, namun selalu mengalami keguguran juga bisa disebut mandul. Infertil disebut juga tidak subur.

Rasullullah SAW menganjurkan memilih calon pasangan yang subur: "Nikahilah wanita yang penyayang dan subur. Karena aku berbangga dengan banyaknya ummatku kelak" (HR Abi Dawud).

Rasulullah SAW bahkan melarang untuk menikah dengan orang yang tidak dapat memberikan keturunan:

"Dari Ma'qil bin Yasar, berkata: seorang laki-laki datang kepada Nabi SAW dan berkata: aku mendapatkan (calon) seorang perempuan yang memiliki status dan kecantikan, namun ia tidak bisa beranak, apakah aku boleh nenikahinya? Nabi menjawab: tidak. Kemudian datang lagi kedua dan datang lagi ketiga kalinya (untuk bertanya lagi). Lalu Nabi menjawab: Nikahilah calon yang penyayang dan potensial beranak. Aku sungguh akan memperbanyak umat ini melalui kalian"(HR Abi Dawud).

\section{Impotensi}

Selain kesehatan yang berhubungan dengan kemampuan untuk memberikan keturunan subur atau tidak subur (mandul), ada juga kesehatan 
yang berhubungan dengan kemampuan untuk melakukan jimak yaitu impotensi.

Impotensi adalah penyakit yang menyebabkan seorang laki-laki yang menderitanya tidak mampu melaksanakan tugas seksualnya (Mugniyah, 2010: 351).

Tidak ada satu definisi yang tepat untuk mengartikan kata impotensi. Banyak yang mengatakan bahwa impotensi adalah ketidakmampuan untuk ereksi yang cukup kuat untuk melakukan hubungan seks. Sementara yang lain mengatakan bahwa impotensi adalah ketidakmampuan penis untuk mempertahankan ereksi yang kuat (Ragg, 2002: 1).

Impotensi berasal dari kata impotent, yang terdiri dari im yang berarti tidak dan potent yang berarti mampu. Jadi secara harfiah impoten artinya ketidakmampuan. Dalam bidang kedokteran, impoten selalu dihubungkan dengan masalah seksual, sehingga impoten diartikan sebagai ketidakmampuan pria untuk melakukan hubungan seks. Secara spesifik, impotensi adalah ketidakberdayaan pria melakukan hubungan seks melalui alat kelaminnya (Wijayakusuma, 2000: 5).

Impotensi adalah penyakit yang menyebabkan seorang laki-laki tidak mampu melaksanakan tugas seksualnya. Dalam keadaan seperti itu, menurut pendapat ulama seluruh mazhab istri dapat membatalkan pernikahan (Mugniyah, 2010: 351). Hal ini bukan hanya terjadi pada seorang laki-laki, namun bisa juga menimpa seorang wanita yaitu tidak dapatnya menikmati hubungan intim karena merasa sakit ketika bersetubuh, secara umum disebut dengan frigit. Dengan demikian tujuan pernikahan untuk pemenuhan kebutuhan biologis manusia tidak tercapai.

\section{Al Jub dan al Khasa'}

Al jub adalah terpotongnya zakar, sedangan al khașa' adalah kehilangan atau pecahnya buah zakar. Adanya yang dua ini pada seorang laki-laki, menurut kesepakatan semua ulama mazhab menyebabkan seorang istri dapat membatalkan pernikahan, tanpa keharusan menunggu bila hal itu sudah ada sebelum hubungan seksual. Sedangkan bila hal tersebut baru terjadi setelah akad nikah dan telah melakukan hubungan seksual, maka istri tidak berhak membatalkan pernikahan (Mugniyah, 2010: 355).

Imam Hanafi mengatakan bahwa, manakala zakar orang yang pelirnya kering itu masih bisa ereksi, sekalipun tidak bisa mengeluarkan sperma, maka istri tidak berhak membatalkan pernikahan. Sedangkan imam mazhab lainnya 
berpendapat bahwa bisa ereksi ataupun tidak, sepanjang tidak bisa mengeluarkan mani, pilihan membatalkan ada pada istri. Sebab, tidak bisa mengeluarkan mani, sama keadaannya dengan impoten (Mugniyah, 2010: 351).

Selama ini, dalam proses kehamilan wanitalah yang sering menjadi perhatian. Padahal, kehamilan merupakan hasil proses pertemuan bibit laki-laki dan perempuan, dimana sebelumnya sel telur dan sperma yang sudah matang harus melakukan perjalanan melalui beberapa organ reproduksi sehat.

Artinya, calon ayah yang sehat, memiliki sperma dan organ reproduksi yang sehat sangat berperan dalam proses menuju kehamilan dan menghasilkan janin yang sehat. Karena begitu pentingnya fungsi sperma dalam proses kehamilan, maka kelainan atau gangguan pada organ tersebut dapat mengakibatkan tergganggunya fungsi reproduksi pria. Ada beberapa gangguan atau kelainan yang menyebabkan sperma menjadi rusak atau tidak berproduksi, diantaranya adalah testis rusak, akibatnya produksi sperma mudah sekali turun atau tidak ada sama sekali. Salah satu adalah al khasa'/ hilang atau terpotongnya buah zakar (BP4 Jakarta, 2010: 14).

\section{Al ritq, al qarn, al 'afal, dan al ifda'}

Kalau pada laki-laki adanya al jub dan al khasa', lalau pada wanita ada penyakit yang disebut dengan Al ritq, al-qarn, al 'afal, dan al Ifda'. Al ritq adalah tersumbatnya lubang vagina yang menyebabkan terjadinya kesulitan bersenggama. Al qarn adalah benjolan yang tumbuh pada kelamin wanita yang mirip tanduk domba. Al 'afal, adalah daging yang tumbuh pada kemaluan wanita yang selalu mengeluarkan cairan, sedangkan al Ifda', adalah menyatunya kedua saluran pembuangan (Mugniyah, 2010: 357).

Keempat cacat ini, kasus yang ada pada kaum wanita. Adanya salah satu dari keempat jenis cacat tersebut pada diri wanita menyebabkannya tidak dapat melakukan aktivitas hubungan seksual, sehingga menurut Imam Maliki dan Hambali, menyatunya kedua saluran pembuangan berhak membatalkan pernikahan. Sedangkan Syafi'i mengatakan bahwa yang menyebabkan terjadinya fasakh adalah al-ritq, dan al-qarn saja. Sedangkan al ifda' dan al 'afal tidak berpengaruh terhadap akad. Menurut Imamiyah, al ifda' dan al qarn mempunyai efek dalam pembatalan pernikahan, sedangkan al ritq dan al 'afal tidak mempunyai efek sama sekali (Mugniyah, 2010: 357-358).

Pensyaratan kesehatan dalam bidang kemampuan untuk jimak merupakan hal yang diperlukan, sehingga dengan demikian tujuan pemenuhan kebutuhan biologis suami atau istri dalam pernikahan dapat tercapai. Ketidakmampuan 
pasangan dalam berhubungan intim sangat berpengaruh terhadap suatu pasangan baik suami atau istri, sebab kebutuhan biologisnya dalam bidang hubungan seksual tidak terpenuhi. Sehingga hal tersebut bisa menjadi alasan pernikahan dapat difaskh.

\section{Hasil Penelitian}

Perceraian atau Poligami yang terjadi di Kabupaten Gayo Lues, diantaranya dipengaruhi oleh faktor biologis dan faktor keturunan. Dari faktor biologis penyebabnya adalah kebutuhan seksual yang tidak terpenuhi, sedangkan dari faktor keturunan adalah pasangan tidak dapat memberikan keturunan.

Terhadap perceraian, para ulama juga sepakat boleh cerai demi kebaikan dan terdapat alasan-alasan yang kuat untuk melakukannya, walaupun ratarata ulama juga memberikan padangannya bahwa cerai perbuatan halal tapi sangat dibenci Allah SWT, namun demi untuk mencari keturunan, atau tidak ingin terjerumus ke dalam perbuatan zina karena ingin memenuhi kebutuhan seksual, perceraian boleh dilakukan kemudian menikah dengan orang lain. Kalau bagi laki-laki boleh saja solusinya berpoligami untuk mendapat keturunan atau ingin memenuhi kebutuhan seksualnya, karena poligami juga tidak dilarang oleh Allah SWT sepanjang masih mengikuti syari'at Islam. Akan tetapi bagi seorang wanita untuk bersuami lebih dari satu orang tidak mungkin dilakukan dan memang tidak dibenarkan oleh agama, sehingga cerai adalah satu-satunya jalan yang boleh ditempuh (Tahmin Ja'far, wawancara, Blangkejeren, 5 Pebruari 2013).

Masalah kesehatan apabila dijadikan sebagai syarat nikah, Ulama Gayo Lues terbagi kepada dua kelompok, ada yang setuju dan ada yang menolak. Mereka yang setuju berpandangan bahwa dalam hal kesehatan, Rasulullah SAW memerintahkan untuk menjauhi orang yang berpenyakit, beliau mengatakan: Larilah engkau dari orang yang berpenyakit lepra, sebagaimana engkau lari dari singa. Masalah kesehatan yang berhubungan dengan pernikahan, sudah diisyaratkan Rasulullah SAW bahwa ketika seseorang hendak menikah maka pilihlah wajah atau kecantikannya, kemudian pilih keturunannya yang baik, lalu pilih yang memiliki harta/ kekayaannya, dan pilih karena agamanya. Hadits ini mengisyaratkan bahwa memilih keturunan termasuk di dalamnya kesehatan, artinya jika keturunannya dari orang-orang yang mempunyai penyakit seperti sulit untuk berketurunan/ tidak subur, maka biasanya orang yang dinikahi tersebut juga tidak jauh berbeda dengan keluarganya (Bahrinsyah, wawancara, Blangkejeren, 4 Pebruari 2013). 
Sebelum menikah, di dalam Islam dianjurkan untuk meminang. Di sinilah kita bisa melihat lebih jauh siapa dan bagaimana sebenarnya keadaan orang yang akan kita nikahi. Maka dalam meminang dibolehkan melihat telapak tangan dan wajah dari orang yang dipinang. Ini terlepas dari perbedaan pendapat para Imam Mazhab tentang apa saja yang boleh dilihat dalam meminang. Artinya dari tepalak tangan dan wajah bagi seorang wanita dapat mewakili kecantikan dan kesuburannya. Ini adalah isyarat-isyarat tentang kesehatan sebelum menikah (Rajudin, wawancara, Terangon, 6 Pebruari 2013).

Hal di atas sangat sejalan dengan adat Gayo Lues, ketika hendak menikah maka akan dicari tahu semua hal tentang calon yang akan dipinang, yaitu dengan ungkapan "risik rise kunul kinte". Maksudnya ketika seseorang hendak menikah harus dilakukan pencaritahuan tentang keadaan keluarga yang hendak dipinang, mulai dari silsilah keturunannya, akhlaknya, apakah penyakit yang dideritanya, apakah keluarganya orang yang bisa memberikan keturunan/ beranak, sampai semua sedetail-detailnya. Hal ini dilakukan salah satunya adalah untuk meminimalisir perceraian di kemudian hari yang disebabkan oleh hal-hal yang telah disebutkan di atas (Rahmah, wawancara, Blangkejeren, 10 Pebruari 2013).

Kemudian, apabila kesehatan dijadikan sebagai syarat pernikahan, maka kesehatan yang dijadikan sebagai syarat pokok apabila penyakitnya sangat fatal, namun apabila penyakitnya tidak begitu fatal maka ia boleh dijadikan sebagai syarat tambahan/kesempurnaan. Ulama tersebut banyak bercerita tentang aib dalam pernikahan ('uyub al nikah) dan beliau menjadikannya sebagai qiyas. Karena menurut beliau dengan fatalnya penyakit seseorang membuat tujuan dari pernikahan itu tidak tercapai. Seperti tidak adanya keturunan, tidak terpenuhi kebutuhan biologis, sehingga sulit juga terhindar dari perzinaan. Ia menyebutkan bahwa menurut kitab-kitab fikih boleh memfasakh pernikahan apabila ada ditemui aib, misalnya putusnya kemaluan laki-laki, tertutupnya kemaluan perempuan, dan lain-lain sebagainya yang bisa menghalangi tujuan dari pernikahan itu sendiri (Syahbudin, wawancara, Putri Betung, 4 Pebruari 2013).

Ulama Gayo Lues juga mengatakan bahwa Rasulullah SAW memerintahkan menikah dengan orang yang banyak keturunan, yaitu: "Nikahilah wanita yang penyayang dan subur. Karena aku berbangga dengan banyaknya ummatku kelak" (HR Abi Dawud).

Hadits ini juga sejalan dengan pepatah Gayo, tentang memilih pasangan yang mampu untuk berketurunan, yaitu: Pilih tebu, si jarang rues si tebel tungku 
(Rajudin, wawancara, Terangon, 6 Pebruari 2013). Dalam bahasa Indonesia maksudnya adalah memilih tebu yang rapat matanya, yang mengibaratkan seorang wanita mampu memberikan banyak keturunan/ banyak anak.

Bahwa syarat nikah dalam fikih bukan qat'i, itu bukan kitab suci, dan boleh dirubah. Namun demikian, bukan berarti Ulama Gayo Lues tidak setuju dengan syarat yang sudah ditetapkan oleh para fuqaha terdahulu, ini demi kebaikan, atau yang disebut maslahah. Artinya kalau memang hal tersebut baik dan bermanfaat bahkan tidak ada mudaratnya, serta tidak melanggar hukumhukum Allah SWT, hal tersebut (masalah kesehatan) boleh ditambahkan sebagai syarat lain demi kesempurnaan syarat yang telah ada, dan demi tercapainya tujuan dari pernikahan itu sendiri yang salah satunya adalah melanjutkan keturunan, serta demi menjaga agar terhindar dari perbuatan zina (Tahmin Ja'far, wawancara, Blangkejeren, 5 Pebruari 2013).

Selanjutnya, ulama Gayo Lues yang tidak setuju jika kesehatan dijadikan sebagai syarat pernikahan menyampaikan beberapa pandangan, yakni sebagai berikut:

"Ulama tersebut melihat sisi lain dari sebuah perceraian, berhubungan dengan kesehatan apabila terdapat aib dalam sebuah pernikahan maka yang boleh dilakukan adalah bercerai. Karena menurut ulama tersebut, kesehatan hanya boleh dijadikan sebagai syarat perceraian apabila terdapat aib dalam sebuah pernikahan, sebab syarat pernikahan sudah qat'i dalam kitab-kitab fikih. Karena di Mahkamah Syar'iyah juga sudah jelas alasan-alasan yang boleh untuk bercerai salah satunya adalah faktor kesehatan" (Muazza, wawancara, Dabun Gelang, 15 Pebruari 2013).

Hal yang sama juga disampaikan oleh Ketua Mahkamah Syar'iyah Kabupaten Gayo Lues yaitu Bapak Zakian, namun ada perbedaan sudut pandang antara Bapak Zakian dengan Tgk. Muazza. Kalau Tgk. Muazza menyatakan tidak setuju kesehatan dijadikan sebagai syarat pernikahan dengan alasan bahwa kesehatan hanya bisa dijadikan sebagai alasan untuk bisa bercerai, sedangkan Zakian berpandangan bahwa kesehatan tidak perlu dijadikan sebagai syarat pernikahan, karena dalam Islam sudah ada khitbah ketika hendak menikah. Khitbah tersebutlah jalan menurut beliau untuk mengetahui kesehatan bakal calon yang hendak dinikahi. Beliau beralasan, seandainya kesehatan dijadikan sebagai syarat pernikahan bisa saja melanggar Hak Asasi Manusia seseorang. Namun beliau setuju kalau kesehatan bebas AIDS/ HIV dijadikan sebagai syarat nikah. Karena menurut beliau AIDS/ HIV merupakan penyakit berbahaya (Zakian, wawancara, Blangkejeren, 6 September 2012). 
Kemudian ulama berpadangan bahwa untuk menjadikan kesehatan sebagai syarat dalam pernikahan perlu kajian lebih mendalam, karena menurutnya syarat-syarat tentang pernikahan sudah jelas. Namun menurut beliau faktor kesehatan sebagai salah satu pertimbangan untuk memilih pasangan hidup. Akan tetapi hal tersebut sifatnya bukan mutlak, karena hal tersebut dikembalikan lagi kepada putusan pribadi yang bersangkutan. Apabila calon pengantin tahu bahwa pasangannya tidak sehat, tetapi dia tetap mau menikah dengannya maka hal tersebut boleh-boleh saja (Laila Asyura wawancara, Blangkejeren, 10 Pebruari 2013). Laila Asyura mengkiyaskan hal tersebut seperti anjuran Rasulullah SAW yang mengutamakan menikahi perawan dari pada janda, bukan berarti tidak boleh memilih janda, begitu pula dalam hal ini, diutamakan untuk memilih pasangan yang sehat secara mental maupun fisik (Laila Asyura, wawancara, Blangkejeren, 10 Pebruari 2013).

Dari uraian di atas dapat dipahami bahwa, untuk kesempurnaan dan kebaikan pernikahan dalam meniti rumah tangga, syari'at yang mengisyaratkan tentang kesehatan. Maka, untuk mencapai kebaikan dan ketenteraman serta kelanggengan rumah tangga perlu memilih pasangan yang sehat, sehingga kesehatan perlu dijadikan sebagai syarat pernikahan untuk mencapai keluarga yang sakinah, mawaddah, wa rahmah.

\section{Pembahasan}

Berangkat dari pengertian pernikahan yang telah dirumuskan oleh para ulama-ulama terdahulu, bahwa nikah adalah akad, dan jimak. Pengertian pernikahan ini memberikan sinyal bahwa pernikahan merupakan salah satu bahagian dari jimak dengan diawali oleh akad, sehingga dalam undang-undang pernikahan disebut sebagai ikatan lahir batin. Selanjutnya, memperhatikan tujuan pernikahan, bahwa secara umum ditegaskan oleh Allah SWT dalam al Quran adalah mencapai keluarga bahagia yang disebut dengan sakinah mawaddah wa rahmah, hal ini dapat dicapai apabila ada beberapa hal lain yang dapat terpenuhi dan dijalankan, misalnya mampu memenuhi kebutuhan seksual pasangan, mampu memberikan keturunan, dan terhindar dari perzinaan. Dengan mampunya memberikan keturunan berarti tujuan pelestarian manusia di muka bumi akan tercapai. Begitu juga dengan mampunya memenuhi kebutuhan seksual pasangan berarti tujuan terhindar dari perzinaan akan tercapai juga. Dan selanjutnya adalah memperhatikan masalah memperhatikan masalah hak dan kewajiban suami istri dalam rumah tangga. Artinya setelah adanya akad nikah, maka kemudian timbul hak dan kewajiban antara suami 
istri. Termasuk di dalamnya adalah hak untuk menikmati dan memenuhi kebutuhan seksual dan hak untuk mendapatkan keturunan.

Terakhir, memperhatikan masalah syarat pernikahan. Ulama fikih kontemporer seperti Wahbah Zuhaili, membagi syarat penikahan kepada empat bagian, yaitu syarat pelaksanaan (in'iqad), syarat sah (sah), syarat terlaksana (nafaz), dan syarat kelanggengan (luz $\llbracket m$ ). Kesehatan jasmani dimasukkan ke dalam syarat sah, yaitu salah satu atau kedua mempelai tidak menderita penyakit yang mengkhawatirkan yang bisa membawa kepada kematian. Sedangkan penyakit mental gila dimasukkan ke dalam syarat terlaksana, yaitu kedua mempelai mempunyai kapasitas sempurna. Kapasitas sempurna itu adalah berakal. Terakhir aib fungsi kelamin dimasukkan kedalam syarat luz $\llbracket m$ (kelanggengan). Tetapi Wahbah Zuhaily tidak menyebut secara tegas dalam syarat pernikahan tersebut terhadap penyakit yang tidak bisa memberikan keturunan.

Dari hasil penelitian di lapangan, penulis menemukan bahwa pandangan Ulama Gayo Lues terbagi kepada tiga kelompok apabila kesehatan dijadikan sebagai syarat pernikahan. Kelompok yang pertama adalah setuju, sedangkan yang kedua adalah tidak setuju dan yang tidak adalah ragu-ragu. Namun mayoritas ulama Gayo Lues setuju apabila kesehatan dijadikan sebagai syarat pernikahan, hanya sebagian kecil saja dari ulama tersebut yang tidak setuju, dan ada juga sebagian kecil yang ragu-ragu. Bagi yang ragu-ragu, artinya mereka tidak bisa memberikan jawaban apakah kesehatan bisa dijadikan sebagai syarat pernikahan atau tidak.

Ulama Gayo Lues yang setuju apabila kesehatan dijadikan sebagai syarat pernikahan memberikan alasan-alasan sebagai berikut: pertama mereka mengambil dalil tentang perintah untuk menikah bagi mereka yang sudah mampu.

"Orang yang tidak bisa untuk berketurunan dan tidak mampu berhubungan intim tergolong kepada orang yang tidak sehat, sehingga mereka belum dianggap mampu" (HR Bukhari).

Dalil kedua yang mereka gunakan adalah hadits tentang menikahi orang yang banyak keturunan: "Mereka yang tidak sehat (tidak subur) tidak mungkin bisa memberikan keturunan" (HR Abu Dawud).

Sedangkan dalil ketiga yang mereka gunakan adalah hadits yang diriwayatkan Bukhari tentang memilih calon ketika hendak menikah yaitu karena empat perkara (wajah/kecantikan, keturunan/orang yang baik dan mampu 
memberikan anak, kekayaan/ harta, dan agama). Menurut ulama tersebut, masalah keturunan tersebut termasuk di dalamnya masalah kesehatan.

Dalil yang terakhir yang digunakan adalah, mereka mengqiyaskan dengan uyub al nikah (aib dalam pernikahan). Menurut ulama tersebut, ketika terdapat aib dalam pernikahan (misalnya, ratq, qarn, al 'afal, al ifda', al jubb al khasa', dll.), pernikahan yang sudah adapun bisa difasakh. Sehingga kesehatan bisa dijadikan sebagai syarat dalam pernikahan.

Ulama Gayo Lues yang tidak setuju kesehatan dijadikan sebagai syarat pernikahan memberikan alasan-alasan sebagai berikut: pertama, mereka memberikan alasan bahwa syarat dalam pernikahan tersebut sudah qat'i dalam kitab-kitab fikih. Mereka melihat sisi lain dari masalah kesehatan, bagi mereka apabila terdapat aib dalam sebuah pernikahan (masalah kesehatan) maka hanya boleh dijadikan sebagai alasan untuk perceraian.

Alasan kedua yang mereka sampaikan adalah: ketika hendak menikakh, di dalam fikih sudah ada khitbah. Khitbah inilah kesempatan untuk mengetahui lebih tentang calon pasangan yang akan dinikahi. Sehingga tidak perlu kesehatan dijadikan sebagai syarat penrikahan. Bahkan apabila kesehatan dijadikan sebagai syarat pernikahan bisa saja akan melanggar (HAM) Hak Asasi Manusia seseorang, sebab ada orang mau menikah dengan seseorang walaupun diketahui bahwa calon pasangannya tidak sehat.

Bagi ulama yang ragu-ragu beralasan bahwa, ketika seseorang harus dinikahkan karena telah melakukan hubungan intim sebelum menikah, kemudian setelah diperiksa ternyata diketahui salah satu pasangannya tidak sehat, apakah mereka tetap tidak akan dinikahkan. Inilah yang membuat mereka ragu apabila kesehatan dijadikan sebagai syarat pernikahan.

Apabila syarat tersebut telah disetujui, kemudian dimasukkan dan dituangkan ke dalam sebuah undang-undang maka syarat tersebut secara formal menjadi syarat yang resmi dan legal, sehingga syarat tersebut menjadi sebuah hukum. Dengan demikian pembentukan syarat menjadi sebuah undangundang/ hukum dapat didekati dengan teori pembentukan hukum.

Apabila didekati dengan teori pembentukan hukum, maka tujuan dari pembentukan hukum adalah bermanfaat atau tidak bagi masyarakat. Teori ini disebut dengan teori utility yang dicetuskan oleh Jeremy Bentham, artinya semakin bermanfaat sebuah hukum terhadap masyarakat, maka semakin baiklah hukum tersebut.

Menurut teori utility, hukum bertujuan mewujudkan semata-mata apa yang berfaidah saja. Hukum bertujuan menjamin adanya kebahagiaan sebanyak- 
banyaknya pada orang banyak. Menurut Bentham, hakikat kebahagiaan adalah kenikmatan dan kehidupan yang bebas dari kesengsaraan. Karenanya maksud manusia melakukan tindakan adalah mendapatkan kebahagiaan yang sebesarsebesarnya dan mengurangi penderitaan.

Artinya dengan dijadikannya kesehatan sebagai syarat pernikahan, maka semakin baiklah kehidupan masyarakat, misalnya dengan adanya syarat kesehatan tersebut dapat meminimalisir perceraian, perselingkuhan, dan perzinaan. Sehingga dengan terhindarnya masyarakat dari keempat hal ini, berarti kehidupan masyarakat sudah menjadi lebih baik. Berarti hukum tersebut bermanfaat bagi masyarakat, maka tujuan pembentukan hukum sudah tercapai yaitu berfaidah membuat kebahagiaan bagi masyarakat.

Sejalan dengan teori utility, di dalam Islam ada kaidah yang dikenal dengan maslahah. Maslahah hampir sama dengan manfaat. Secara terminologi, maslahah yaitu mengambil manfaat dan menolak mudarat. Sehingga untuk menetapkannya menjadi sebuah hukum, maka hukum tersebut harus bermanfaat dan bernilai baik serta membuang mudaratnya. Artinya tidak hanya dilihat segi manfaat saja, tetapi juga harus diperhatikan mudaratnya (pertimbangan baik atau tidaknya/ bertentangan atau tidak dengan hukum Islam yang telah digariskan oleh Syari'). Inilah yang membedakannya dengan teori utility yang hanya mengedepan manafaat tanpa diimbangi oleh maslahah. Sedangkan menurut kaidah ini, disamping manfaat juga harus maslahah.

Setelah memperhatikan hal-hal tersebut di atas, pandangan ulama yang menyebutkan bahwa kesehatan bisa dijadikan sebagai syarat pernikahan lebih memenuhi unsur-unsur kaidah maslahah dan sesuai dengan teori manfaat (utility). Sebab dengan dijadikan kesehatan sebagai syarat pernikahan, maka tujuan pernikahan untuk mencapai keluarga sakinah, mawaddah, wa rahmah akan tercapai. Sehingga dengan dengan demikian dapat meminimalisir perceraian, perzinaan, dan tidak terputusnya generasi umat Islam.

Sebaliknya, apabila kesehatan kurang, sehingga tidak mampu memberikan keturunan atau tidak mampu memenuhi kebutuhan seksual pasangan maka semua yang telah disebutkan di atas mulai dari pengertian pernikahan, tujuan pernikahan, dan hak serta kewajiban suami istri tidak akan tercapai.

Terhadap pandangan ulama yang tidak setuju apabila kesehatan dijadikan sebagai syarat perkawinan, maka akan berdampak terhadap putusnya generasi umat Islam apabila menikah dengan orang yang tidak sanggup memberikan keturunan, dan perzinaan akan meningkat diakibatkan oleh pasangan tidak mampu memenuhi kebutuhan seksual. Dan apabila ditinjau dari teori 
manfaat dan kaidah maslahah belum memenuhi kedua unsur ini, lebih banyak mudaratnya dari pada manfaatnya apabila kesehatan tidak dicantumkan sebagai syarat pernikahan.

\section{Simpulan}

Perceraian boleh dilakukan kalau terdapat alasan-alasan yang kuat untuk melakukannya salah satunya adalah alasan faktor kesehatan, karena perceraian bukan merupakan hal yang haram untuk dilakukan. Sebab orang yang tidak memiliki organ reproduksi yang sehat tidak akan bisa jimak, begitu juga dengan orang yang mandul tidak dapat memberikan keturunan. Sehingga, cerai kemudian menikah lagi untuk memenuhi kebutuhan seksual atau untuk mendapatkan keturunan, maupun untuk menghindari dari perzinaan lebih bermanfaat daripada mempertahankan keluarga tersebut.

Mayoritas ulama Kabupaten Gayo Lues setuju apabila kesehatan dijadikan sebagai syarat dalam pernikahan, karena ulama terdahulu juga memasukkan aib fungsi kelamin kepada syarat nafaz (syarat terlaksananya pernikahan). Namun ada sebahagian kecil ulama yang tidak setuju, mereka beralasan bahwa syarat nikah sudah jelas dalam kitab-kitab fikih yang telah dibuat oleh para ulama terdahulu. Sedangkan bagi mereka yang ragu-ragu beralasan bahwa, ketika seseorang harus dinikahkan karena telah melakukan hubungan intim sebelum menikah dan ternyata setelah diperiksa ternyata diketahui ada yang tidak sehat apakah harus dibatalkan pernikahannya, sehingga mereka ragu hal ini akan berjalan apabila tetapi dijadikan sebagai syarat pernikahan.

\section{Daftar Pustaka}

Ahmad, Rulam. 2005. Memahami Penelitian Kualitatif. Malang: Universitas Negeri Malang.

Asikin, Zainal dan Amiruddin. 2006. Pengantar Metode Penelitian Hukum. Jakarta: Raja Grafindo Persada.

Badan Penasihatan Pembinaan dan Pelestarian Perkawinan. 2010. Majalah Perkawinan dan Keluarga, No. 458/xxxviii/2010. Jakarta: BP4 Pusat.

Burhanuddin S. 2010. Nikah Siri. Yogyakarta: Pustaka Yustisia.

Moloeng, Lexi, J. 2002. Metodologi Penelitian Kualitatif. Bandung: Remaja Rosdakarya. 
Muhammad, Husein. 2007. Fiqh Perempuan; Refleksi Kiai atas Wacana Agama dan Gender. Yogyakarta: LKIS.

Mugniyah, M. Jawad. 2010. Fiqih 5 Madzhab. Jakarta: Lentera.

Nasution, Bahder Johan. 2008. Metode Penelitian Ilmu Hukum. Bandung: Mandar Maju.

Qondil, Abdul Munim. 2003. Nikah Itu Enak; Mengapa Takut Menikah. Solo: Ma'sum Press.

Ragg, Marg. 2002. Mengatasi Impotensi. Jakarta: Arcan.

Sugiono. 2008. Metode Penelitian Kuantitatif, Kualitatif dan REDD. Bandung: Alfabeta.

Thalib, Muhammad. 1995. 40 Tanggung Jawab Suami terhadap Istri. Bandung: Irsyad Baitussalam

Tualeka, Hamzah ZN. 2011. Kearifan Lokal Pelagandong di Lumbung Konflik. Jurnal El Harakah Vol. 13 No. 2 Juli Desember 2011.

Wijayakusuma, Hembing. 2000. Mengatasi Impotensi Secara Efektif dan Alamiah. Jakarta: Elex Media Komputindo.

Zuhaili, Wahbah. 2007. Fikih Islam Wa'adilatuhu. Terj. Abdul Hayyie al Kattani, dkk. Jakarta: Gema Insani. 